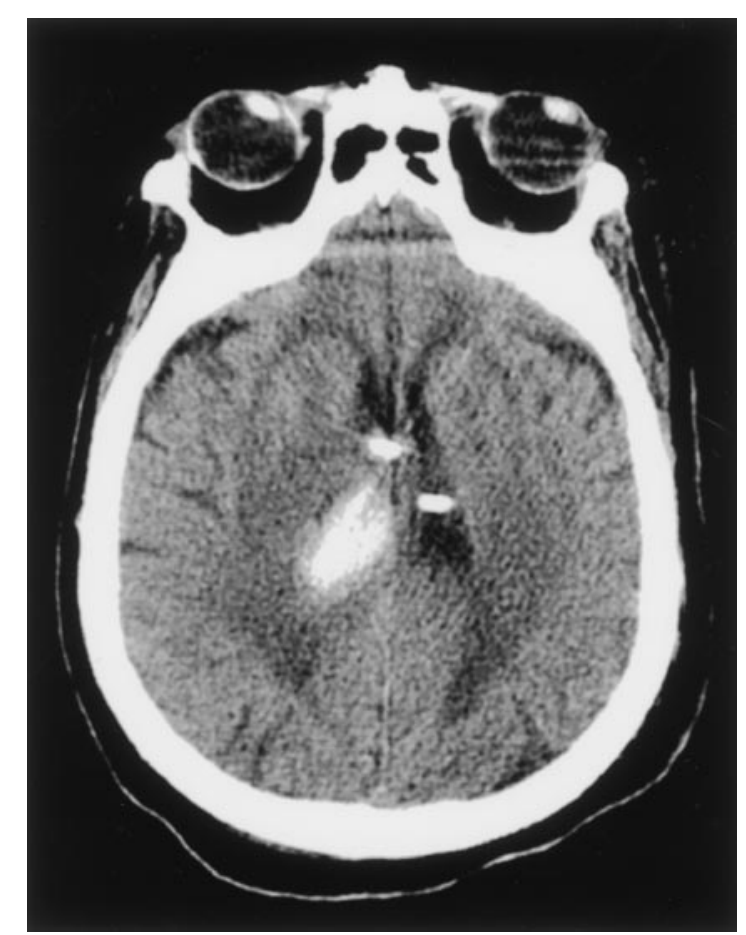

Figure. CT image of the head reveals a right thalamic hemorrhage with intraventricular extension. Marked left gaze deviation is apparent in the orientation of the ocular globes and lenses bilaterally, and ventriculostomy catheters are present in both lateral ventricles.

\section{Wrong-way eyes with thalamic hemorrhage}

Steven R. Messe, MD, and Brett L. Cucchiara, MD, Philadelphia, $P A$

An 85-year-old woman with a history of hypertension was found unresponsive in her home. On arrival in the emergency department, she was obtunded with left-gaze deviation and left-sided weakness. Initial head CT revealed a right thalamic hemorrhage with intraventricular extension and early hydrocephalus, requiring ventriculostomy placement. Follow-up CT (figure) showed this hemorrhage and, in the same cross-sectional image, revealed marked left deviation of her ocular globes and lenses.

Following supratentorial infarction or hemorrhage, there is often conjugate gaze deviation toward the side of the lesion due to injury to the descending supranuclear ocular motor pathways. However, thalamic hemorrhage (and rarely large lobar hemorrhage) can present with gaze deviation away from the side of the lesion, so-called "wrong-way eyes." 1 Proposed mechanisms explaining this observation include compression of the mesencephalon affecting crossed frontopontine fibers, irritative effects on the intralaminar thalamic nuclei, or an interhemispheric smooth pursuit imbalance. ${ }^{2}$

1. Fisher CM. Some neuro-ophthalmological observations. J Neurol Neurosurg Psychiatry 1967;30:383-392.

2. Tissen CC. Contralateral conjugate eye deviation in acute supratentorial lesions. Stroke 1994;25:1516-1519.

Address correspondence and reprint requests to Dr. Brett L. Cucchiara, Comprehensive Stroke Center, Department of Neurology, University of Pennsylvania Medical Center, 3400 Spruce Street, Philadelphia, PA 19104; e-mail: cucchiar@mail.med.upenn.edu 


\section{Neurology}

\section{Wrong-way eyes with thalamic hemorrhage}

Steven R. Messe and Brett L. Cucchiara

Neurology 2003;60;1524

DOI 10.1212/01.WNL.0000065900.62880.4F

\section{This information is current as of May 13, 2003}

\section{Updated Information \&} Services

\section{References}

Citations

Subspecialty Collections

Permissions \& Licensing

Reprints including high resolution figures, can be found at: http://n.neurology.org/content/60/9/1524.full

This article cites 2 articles, 2 of which you can access for free at: http://n.neurology.org/content/60/9/1524.full\#ref-list-1

This article has been cited by 1 HighWire-hosted articles: http://n.neurology.org/content/60/9/1524.full\#\#otherarticles

This article, along with others on similar topics, appears in the following collection(s):

All Cerebrovascular disease/Stroke

http://n.neurology.org/cgi/collection/all_cerebrovascular_disease_strok e

Intracerebral hemorrhage

http://n.neurology.org/cgi/collection/intracerebral_hemorrhage Ocular motility

http://n.neurology.org/cgi/collection/ocular_motility

Information about reproducing this article in parts (figures,tables) or in its entirety can be found online at:

http://www.neurology.org/about/about_the_journal\#permissions

Information about ordering reprints can be found online:

http://n.neurology.org/subscribers/advertise

Neurology ${ }^{\circledR}$ is the official journal of the American Academy of Neurology. Published continuously since 1951, it is now a weekly with 48 issues per year. Copyright . All rights reserved. Print ISSN: 0028-3878. Online ISSN: 1526-632X.

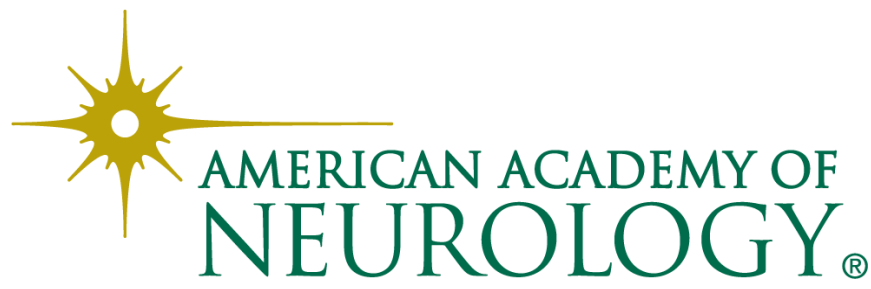

